\title{
Research in Tropical Protected Areas: Some Guidelines for Managers
}

\author{
by \\ JAmes W. ThORSEl, MA (Western Ontario), PhD (UBC) \\ Visiting Fellow, East-West Center, \\ Environment and Policy Institute, \\ Honolulu, Hawaii, USA; currently \\ Programme Coordinator, \\ IUCN Commission on National Parks and Protected Areas, \\ The World Conservation Centre, \\ Avenue du Mont-Blanc, 1196 Gland, \\ Switzerland.
}

\section{INTRODUCTION}

National parks and other protected areas represent an approach to resource use that provides a multiple flow of benefits to society (Bourlière, 1962). Such areas safeguard outstanding land- and seascapes, maintain biodiversity, protect water catchments, minimize erosion, act as catalysts for environmental education, stimulate tourism, and provide for a wide range of recreational uses. Parks and reserves in the tropics also carry international recognition as repositories of important genetic and other research resources, because they protect significant natural areas that contain over two-thirds of the planet's biodiversity.

A classic example of the enormous contribution of applied research that is carried out in natural areas is evident in Ecuador's Galápagos Islands. Beginning with Charles Darwin, the scientific observations made there over the past century have greatly benefited Mankind's understanding of the processes of evolution and island biogeography. An examination of any textbook on ecology or pertinent learned-society journal similarly reflects the values that secure natural 'benchmarks' provide for our understanding of the natural world. Indeed, a major mission of the world network of 273 Biosphere Reserves (of which 73 are located in the four tropical realms) is to act as a focus for scientific research and monitoring.

Although it is true that parks are often ideal scientific laboratories, it must also be recognized that research workers have potential for causing environmental damage and can conflict with other uses. For example, they have often interfered with park visitors at key sites, and in other cases excessive collecting of specimens has depleted the resource. Moreover, certain kinds of research need to be avoided altogether for example, studies that involve the deliberate introduction of alien organisms to oceanic islands. So, like other uses of protected areas, attention to directing or at least controlling research activities is required.

The objectives of this paper are, first, to review the research needs and opportunities in parks and reserves, and, second, to suggest some guidelines on how managers can best direct the conduction of, and facilitate, research. The orientation is thus towards the park manager's perspective rather than the scientist's, although the interests of both groups are usually coincident.

\section{Research in Protected Areas: NeEdS AND OPPORTUNITIES}

Human influence on the planet is already too great to imagine that any protected area is still totally 'natural' or stable. Protecting anything of Nature, whether it be a single species or a whole representative ecosystem, requires management intervention to ensure that the desired environment is maintained. To manage protected areas with any degree of efficiency and safety, the manager must first know and understand the way in which the various ecosystems involved operate, and the effects of Man upon them (McKercher \& Dingwall, 1983).

Five basic topics can be identified for which the manager will require accurate, scientifically-collected, biophysical information before he (or she) can prepare a comprehensive plan for the long-term management of a protected area:

1) Inventory. What plants, animals, and other natural resources, are present? Are there reliable estimates of species and population densities? How are they distributed in space and time? What are the important medicinal plants and other wild relatives of domestic species? What are the water-runoff rates and amounts of measurable pollution? Are there geological and soil maps? What are the threats to the park?

2) Species needs. As much information as possible should be gathered on status, particular habitat requirements, shelter, food, minerals, and water-needs of species of special management significance.

3) Ecological relationships. What animal eats what? What plant competes with what? What otherwise depends on what? What are the key species maintaining the integrity and functioning of the ecosystem?

4) Monitoring and dynamics of change. Studies are needed on colonization and restoration of disturbed areas, invasion by new species, changes of river flow 
or quality, and population trends within species. Is there evidence of climatic change?

5) Predictive manipulation of ecosystems. Where the natural processes of change are contrary to the objectives of management, the manager will want to prevent change or affect its direction. To do this will require special knowledge of the direct and indirect, short-term and long-term, effects of different management options on ecosystem processes.

Apart from the biophysical topics, a manager will need information on the effects of his or her reserve on the local economy and society. He or she must also be aware of the effects, on the reserve, of visitor use and other human activities. One of the first tasks of the manager is thus to incorporate a social research programme identifying the research needs and giving some indication of priority or urgency while suggesting who might conduct such research.

Topics on which managers require socio-economic information include:

1) Resident and neighbouring populations:- How do local people perceive and use the reserve? What benefits do they receive, and what are the direct costs to them? How best can their cooperation be fostered? What traditional knowledge of the use of the reserve's resources has been documented? What is the history of human occupation?

2) Economic valuation:- What are the estimates of the reserve's economic values in terms of protecting watersheds and fisheries, ensuring biodiversity conservation, tourism expenditures, and its role in regional economic development and local employment? Which values can be quantified?

3) Recreation and tourism:- What is the market area of of the reserve? How many visitors use the reserve? Where and when? What other attractions and opportunities are found in the region? What impacts (environmental and economic) do they have? What are the attitudes and opinions voiced before and after their visit? Are facilities and services adequate? How can 'nature tourism' best be encouraged in the context of the particular reserve?

4) Management and administration:- How effective is is the legal basis for the reserve? What staff-training methods are most effective? What are the administrative and policy frameworks available? What are the best mechanisms to ensure staff recruitment and cooperative arrangements with local authorities and private organizations? What are the linkages between the reserve and surrounding lands? What is the best means to obtain public participation? How could international programmes and conventions be used to foster and support research in the reserve?

The manager must decide which research activities to encourage vigorously, which to aid, and which merely to allow if they do not interfere with other management activities. In determining these priorities, the manager must be largely influenced by the nature of the particular reserve, its level of human use and proximity to local populations, park objectives, the complexity and extent of its resources, and the amount of knowledge already available to him or her through previous research.

Some proposed research projects may appear purely academic and have no immediately obvious management value. These should nevertheless be encouraged unless they conflict with reserve objectives, tie up valuable resources, or interfere with current management practice, as their findings may prove of value later or elsewhere. The manager should not shy away from studies that may be critical of management, and should attempt to foster a free and open dialogue between managers and research workers.

It follows that management plans for protected areas will include a section outlining the research programme. This is the case for several reserves, such as the Galápagos (Ecuador), Dumoga (Indonesia), Manu (Peru), Haleakala (USA), Mapimi (Mexico), and Monteverde (Costa Rica), in each of which the plan identifies the topics that management defines as priorities. A research prospectus has also been prepared for Dominica's Morne Trois Pitons National Park (Island Resources Foundation, 1979) and such 'proactive' approaches are to be encouraged.

\section{Suggested Guidelines fOR MANAGING ResearCh Activities in Protected AREAS}

Along with recognition of the research opportunities of a particular area, it is also important for the management authority to have a clear policy of what research it will encourage or merely allow, and on what terms. This will help to stimulate research, indicate to scientists how they could best contribute to management, and ensure that research activities do not cause unnecessary disruption to the reserve. Most countries have formulated such national-level regulations. Nepal, for example, requires employment of a local counterpart at the foreign research worker's expense. Moore (1984) has included a section on suggested research policies and regulations in the FAO Conservation Guide: 'Operations Manual for a Protected Areas System'.

Based on these materials and IUCN's handbook on Managing Protected Areas in the Tropics (Mackinnon et al., 1986), the following ten guidelines are proposed as the basis of a national policy on managing research in tropical protected areas:

\section{Identify the information needed for management of} the park, and include a section on research and monitoring in the management plan:- Each park will have different management objectives and specific management issues that may require special attention. Assistance from local universities, research institutes, national and other museums, archives, and international programmes (e.g. UNESCO's Man and the Biosphere Programme), can be obtained in preparing the research component of the management plan. The park zoning plan may also suggest certain areas in which studies, designed to bring human uses into balance with the environment, are encouraged, while the inner core might be zoned for more secluded and long-term ecological studies. 
2. Promote the use of the protected area as a site for research activities:- Managers should be researchoriented just as much as research workers should be management-oriented. If protected areas are to contribute fully to sustaining society, their role as laboratories for research and as monitors of natural systems needs to be actively pursued. This may mean building working relationships with local universities and colleges, or arranging special agreements with research institutes (e.g. The Smithsonian Tropical Research Institute in Panama). Facilities such as research stations and special study-zones also act as incentives to facilitate scientific study. At the very least, each reserve should have a system for long-term monitoring of basic components such as wildlife populations, vegetation changes, water quality, weather, and visitor use. Much of this work can be carried on by resident park staff who have had basic training in systematic sampling techniques and the use of micro-computers.

3. Ensure that social and economic research programmes are given adequate attention:- As most problems facing park managers today are at the park/people interface, research on the human aspects of protected areas management should be given much greater support than has been usual hitherto. Managers also need to be able to quantify, and bring to the attention of administrators, the many financial and economic benefits that protected areas provide through conservation of biodiversity, protection of watersheds, tourism, etc. Economic techniques that can be used to estimate benefits and costs of protected areas are being summarized in Dixon \& Sherman (in press). A country-wide benefits study has also recently been completed in Thailand (Dobias et al., 1988).

4. Require approval of all research projects before they commence:- The protected area management authority will first want to ensure that any unsolicited project is compatible with the objectives of the reserve, or at least is not incompatible in any way. The manager may also request modifications of a project - to make it more relevant to management needs, or to complement other research projects in the area. In assessing proposals, the management authority will want to confirm the adequacy of the research design and the credibility of the investigator responsible. Some countries require that research workers post a bond before a permit is granted.

5. Monitor activities of research workers in the field: - The manager must retain control over all activities in the protected area, including those of research workers. This may mean that the reserve manager gives prior approval of research workers' travel and work schedules or may, for management reasons, place restrictions on such activities. Research workers should also be required to submit periodical written progress reports and, when appropriate, occasional presentations of their findings to protected-areas staff. The manager should also recognize that the presence of research workers in some parks can assist management indirectly, for example by keeping tracks open and acting as a deterrent to poachers. Research facili- ties must be maintained at the highest environmental standards, and situations must be avoided such as those in research centres in Antarctica where waste and local pollution are common (Tangley, 1988).

6. Devote special attention to collection of specimens:- Collection of plant and animal materials in the reserve must require specific permission and the manager may wish to request duplicate specimens and identifications to be deposited in the protected area herbarium or in a national museum. Material to be taken outside the country may require a special permit from the relevant national scientific institute, which again may request duplicate specimens or the return of valuable material after examination. As most tropical parks harbour valuable genetic resources, regulations for collection of seeds and reproductive materials need to be formulated. Removal of archaeological specimens or any other rare materials should be limited to very minimal amounts.* Public relations' pacification efforts may be necessary when visitors and local people see materials being removed to which they do not themselves have access.

7. Minimize the disruptive effects of social and anthropological research:- Research on park users can involve intensive interviews and long questionnaires which may or may not be well-received by tourists and local residents who are generally, though not always, receptive of these methods. Maximum use should be made of non-obtrusive measures that are less noticeable but still are valid techniques (e.g. direct on-site observation). In protected areas that have resident human populations, special care will have to be taken to avoid deleterious effects on the cultural integrity of people whose way of life the area is designed to protect.

8. Return financial benefits from research activities to local communities:- Expenditures by research workers (equipment, support staff, etc.) can be an additional factor in justifying the rationale for a protected area. In Costa Rica's Guanacaste National Park, for example, scientists spend an estimated $\$ 200,000$ per year for local support services and this figure is expected to reach $\$ 1$ million as the research programme expands. Research workers should, therefore, be encouraged to patronize local businesses in the region, thereby increasing public support for conservation.

9. Maintain a record of all research undertaken in the reserve:- On completion of the study, the research worker should submit a full final report on his project, including a compulsory section on the relevance of the findings to conservation in the area. Each research worker should be required to send, to the management authority, copies of all publications that arise from his or her research in the reserve, and should duly acknowledge in such publications the assistance of the reserve management and (where relevant) staff.

*Cf. e.g., 'For Geologists: A Code of Conduct for Rock-coring', by Dr J. Eric Robinson, published in our latest issue (Environmental Conservation, 16(4), pp. 371-2, 2 figs, 1989). -Ed. 
Summaries written in a popular style can then be used in interpretive literature on the park. Original qualitative and quantitative data should be available in the reserve's files on the assurance that these will be used only for management purposes and will not be quoted for an agreed period or until the research worker himself or herself releases the information. Publicly available copies of all research reports, and a bibliography of all research conducted in the park, should be part of every park reference library.

10. Consider the appointment of a staff research scientists:- For many protected areas - particularly those that have been designated Biosphere Reserves and thus carry a special responsibility for scientific research - a full-time staff position as 'park scientist' is warranted and often essential. Such a position should be independent, in order to allow freedom to criticize management activities when warranted. The park scientist should act to support the above nine activities as well as coordinate the park's research and monitoring programme. Another option would be to consider an agreement with a university, college, or other suitable concern, to perform the same function. In any case, a budget-line directed to supporting research activities should be included by the park manager in his or her financial planning.

\section{ACKNOWLEDGEMENTS}

A first version of this paper was prepared for a FAO workshop on research in protected areas that was held in the Galápagos Islands in March 1989. I wish to thank my colleagues at IUCN, the East-West Center, the University of Hawaii, and staff at Hawaiian Volcanoes National Park, for their comments on an earlier draft.

\section{CONCLUSION AND SUMmaRY}

A major reason for establishment of parks and reserves is to provide secure areas for long-term studies on the biophysical components of The Biosphere. Research, therefore, should be seen as a legitimate and essential, indeed routine, activity in most protected areas, and particularly in the biologically rich reserves in the tropical countries. But, as with any other use, research needs to be planned and the execution of its results effectively managed. Protected-area management authorities must accordingly have a clear policy of what research they will actively encourage and how



FIG. 1. Entrance to the research station at Cocha Cashu in Peru's Manu World Heritage Site. Established in 1969, it has been one of the most productive scientific facilities in the humid tropics. Between 20 and 30 research workers are usually present at any one time, and several hundred scientific papers and articles on the Manu environment have already been published. Photo: Dr James W. Thorsell. 
to ensure that the results are applicable by management. This paper reviews the range of research topics for which tropical protected areas provide opportunities, and suggests some guidelines on how the protected-areas management authority can most effectively direct and utilize the results of research programmes.

Over the past decade there has been a shift in management policy which affects the role of science in protected areas. Managers today are demanding information relating to emerging issues of conservation biology, biodiversity, environmental monitoring, genetic variability, restoration ecology, climatic change, human sociology, and the role of protected areas in regional development. Some tropical parks have strong scientific programmes (e.g. Galápagos [Ecuador], Manu [Peru] - Fig. 1, Guanacaste [Costa Rica], Sinharaja [Sri Lanka], Volcanoes [Hawaii], Serengeti [Tanzania], Kruger [South Africa], Bharutpur [India], Kakadu [Australia], Sian Kaan [Mexico], Aldabra [Seychelles], and Chitwan [Nepal]; but most areas do not have a systematic approach to research. If protected areas are to reaffirm their value as scientific resources, more attention must be given to fostering research as a basic need rather than an optional extra. Moreover, with the growing scarcity of natural areas and with increasing public concern for biodiversity conservation, the scientific values of tropical protected areas are being elevated in importance. Corresponding changes in the way these reserves are viewed and used can be anticipated.

\section{REFERENCES}

BourliERE, F. (1962). Science and parks in the tropics. Proceedings of the First World Conference on National Parks. IUCN, Morges, Switzerland. Pp. 63-68.

Dixon, J.A. \& SHERMAN, P.B. (in press). The Economics of Protected Areas. Island Press, Covelo, Colorado, USA.

Dobias, R.J., TeCH, T. \& Wangwacharakul, V. (1988). Beneficial Use Quantifications of Huai Kha Khaeng, Thailand. Report to World Wide Fund for Nature (Project 3757). WWFInternational, 1196 Gland, Switzerland: 50 pp., mimeogr.

IsLAND RESOURCES Foundation (1979). A Research Prospectus for the Dominica National Park Programme. Contract report prepared for Canadian Nature Federation, Ottawa, Ontario, Canada: $12 \mathrm{pp}$.

Mackinnon, J. and K., ChILd, G. \& Thorsell, J.W. (1986) Managing Protected Areas in the Tropics. IUCN/UNEP, Gland, Switzerland: $295 \mathrm{pp}$.

MartinKa, C.J. (1985). New role for science in National Parks. Pp. 367-73 in Transactions of the 50th North American Wildlife and Natural Resources Conference. Wildlife Management Institute, Washington, DC, USA [not available for checking].

McKercher, N.D. \& Dingwall, P.R. (1983). Identifying the essential scientific needs of protected area managers. Pp. 320-30 in Conservation, Science and Society. Proceedings of the First International Congress on Biosphere Reserves, Minsk, USSR, UNESCO/UNEP, Paris, France: [not available for checking].

MoORE, A.W. (1984). Operations Manual for a Protected Areas System. FAO Conservation Guide 9, FAO, Rome, Italy: 85 pp.

Stoltenberg, C.H. (1970). Planning Research For Resource Decisions. Iowa State University Press, Ames, Iowa, USA: 236 $\mathrm{pp}$.

TANGLEY, LauRA (1988). Who's polluting Antarctica? BioScience, 38(9), pp. 590-4. 